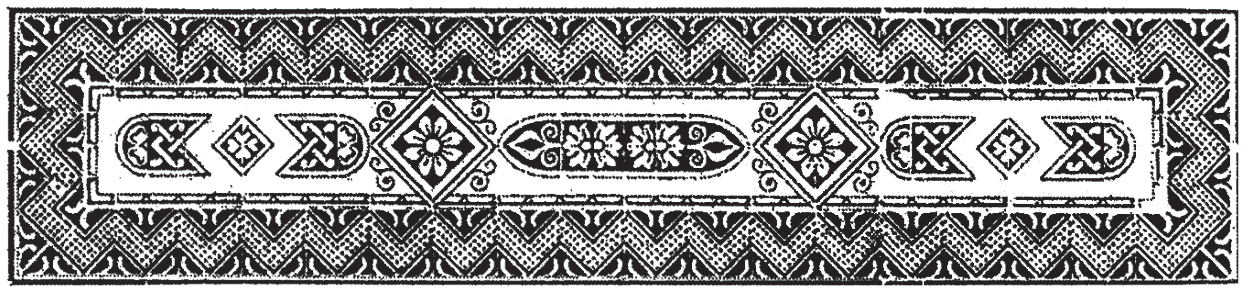

doi https://doi.org/10.18485/bratstvo.2021.25.2 УДК $003=163.41 " 20 "$

Рад примљен: 10. 8. 2021.

Рад прихваћен: 9. 9. 2021.

Оригиналан научни рад

\title{
СРПСКА ЋИРИЛИЦА ДАНАС
}

У овом прилогу укратко се представља актуелна језичка ситуација која је одраз расправа које су се водиле о српској ћирилици и о закону о службеној употреби језика и писма. Аутор се позива на догађаје и расправе вођене од 2017. године до данас.

1. Могуће је да ће будући историчари српскога стандардног језика другу и трећу деценију XXI века једнога дана описивати као кључни период за судбину српске ћирилице. Унутрашњи и спољашњи напади на српско национално писмо, наравно, нису нестали нити ће нестати, али су и напади на српску ћирилицу и њена одбрана променили форме. У овоме прилогу задржаћемо се више на механизмима данашње одбране, које не можемо схватити без ширег контекста. Постепено потискивање ћирилице у сфери јавне, па чак и службене употребе, наиме, почело је да нагриза и основну поставку из Члана 10 Устава Републике Србије, по којој је у службеној употреби само „српски језик“ и „ћириличко писмо“, као и одговарајуће чланове Закона о службеној употреби језика и писама. И овај закон, иако сасвим анахроничан будући да је 1991. године донесен за потребе друге и другачије државе од данашње Републике Србије, на исти начин регулисао је статус ћирилице као јединог службеног писма. Увиђајући несклад између уставних и законских поставки с једне стране, и с друге стране реалне праксе у јавном језику, где је ћирилица практично нестајала (медији, рекламе, јавни исписи и натписи и сл), Министарство културе и јавног информисања још 2017. године решило је да реагује. Тадашњи министар 
културе Владан Вукосављевић и специјални саветник министра културе Драган Хамовић окупили су те године, у сарадњи са Одбором за стандардизацију српског језика, четворочлану групу србиста коју су чинили Срето Танасић, Милош Ковачевић, Вељко Брборић и Александар Милановић. Лингвистичком тиму прикључио се и тим правника у изради Измена $u$ допуна Закона о службеној употреби језика и писама. Израду овог документа пратио је низ координисаних активности, првенствено у научној, медијској и образовној сфери, који је подразумевао објављене текстове, јавне наступе, трибине, предавања, семинаре намењене наставницима и професорима матерњег језика и књижевности и сл. Истовремено је у медијима кренуо и низ напада на српску ћирилицу, у којима су браниоци ћирилице представљани као нападачи на латиницу иако законски статус допунског српског писма никада и нигде није довођен у питање.

2. У процес научне анализе положаја ћирилице у Србији, али и у другим словенским срединама, укључио се веома активно и београдски Међународни славистички центар. И овај центар, са великим реномеом у свим словенским срединама, и Министарство културе и информисања Републике Србије уочили су повећано интересовање не само стручне јавности за потешкоће око решавања законског статуса ћирилице и на њега су одговорили организацијом округлог стола „Употреба ћирилице у јавном простору (службена и јавна употреба ћирилице)“ у оквиру 49. Научног састанка слависта у Вукове дане. Округли сто је одржан 12. септембра 2019. године у Сали за седнице Филолошког факултета у Београду, а одабрани простор био је испуњен заинтересованим домаћим и страним србистима и славистима, као и новинарима различитих медијских агенција. Уводничар и модератор округлог стола био је проф. др Милош Ковачевић, а учешће у раду узели су угледни слависти из словенских држава у којима је ћирилица службено писмо и истовремено дугогодишњи сарадници Међународног славистичког центра у Београду: проф. др Галина Тјапко из Русије, проф. др Димка Савова из Бугарске, доц. др Олга Новак из Украјине и доц. др Светлана Гољак из Белорусије. Сви учесници су сажето и прецизно представили законска решења о службеној и јавној употреби писма у њиховим земљама. У средиште излагања и разговора на округлом столу, што је видљиво и из његовог именовања, тако је стављено суштинско питање функционисања ћирилице у Србији, а то је појмовно и суштинско разграничавање појмова службена употреба и јавна употреба. Велико интересовање јавности за ово питање препознао је и дневни лист „Политика“", који је најконкретније реаговао на округли сто, прво извештајем под насловом Подршка ћирилици у броју од 14. септембра 2020. године (стр. 21), који почиње речима: „Министарство културе и информисања подржало је закључке са округлог стола посвећеног употреби ћирилице у јавном простору одржаног у четвртак на Филолошком факултету у Београду, у 
којима је недвосмислено истакнуто да је ћирилица идентитетско писмо које друштво мора да негује и развија, те да је неопходно да се што пре редефинише законска регулатива која се тиче службене и јавне употребе ћирилице, саопштено је из овог министарства.“ Потом је „Политика“ у недељном броју од 13. октобра 2020. године имала и тему недеље: „Шта кочи усвајање закона о језику и писму“. Тим поводом редакција је организовала и нови округли сто, на којем су учествовали састављачи предлога допуна и измена Закона из редова србиста. Темат је захватио чак четири стране текста, рачунајући и насловну (стр. $1,11,12$. и 13).

3. Нажалост, и поред повећаног научног, стручног и медијског интересовања за нови, актуелној језичкој ситуацији адекватан Закон о службеној употреби језика и писма, који би, између осталог, и ћирилици у Србији вратио достојанствен статус који због своје традиције и вишевековне службе у српској култури и заслужује, и овај предлог измена и допуна постојећег закона завршио је „у фиоци“, доживевши тако судбину сличног предлога Министарства културе и информисања из 2004. године, који је тада саставио Бранислав Брборић. На парадоксалну поставку у српској култури и језичкој политици, у којој ни нови предлог надлежног министарства није дошао до оних којима је упућен, реаговало је у више наврата и Министарство културе и информисања Републике Србије, што је најдетаљније преносио дневни лист „Вечерње новости“. На пример, у броју од 6. јула 2019. године текст је на насловној страни најављен наднасловом Варнице око новог закона и насловом Ко кочи заштиту ћирилице, док је на четвртој страни, под конкретнијим наднасловом Начрт Закона о службеној употреби језика две године „путује“ од министарства до народних посланика и насловом Заштита ћирилище закочена у влади, објављен текст који преноси негодовање министра Владана Вукосављевића, али и морални чин оставке као реакцију на опструкције, коју је поднео специјални саветник министра културе Драган Хамовић, уважени песник, књижевни критичар.

4. Осим у фреквенцији и дистрибуцији новинских текстова, повећано интресовање за законски статус српске ћирилице у оквиру више држава (Србија, Српска, Босна и Херцеговина, Црна Гора, Хрватска), али и за њен реални статус у свакодневици, огледало се и у научној продукцији, па је управо 2019. објављен у Бањој Луци зборник радова Српски језик и српско писмо данас (главни уредник Рајко Кузмановић, одговорни уредник Драгољуб Мирјанић, приређивач Слободан Реметић), у којем су штампани реферати са истоименог округлог стола, а који је објавила Академија наука и умјетности Републике Српске. Зборник Српско језичко и књижевно насљеђе на простору данашње Црне Горе: Српски језик и књижевност $\partial a н a c$, у издању троимене институције или трију институција делом истог имена (Матица српска - Друштво чланова у Црној Гори, Матица српска и 
Матица српска - Друштво чланова Матице српске у Републици Српској) исте године донео је под уредништвом Јелице Стојановић више реферата посвећених актуелним проблемима функционисања ћирилице у Црној Гори. И у зборнику радова Нови прилози српском правопису из 2019, у издању Матице српске и Андрићевог института (ур. одбор Драган Станић, Срето Танасић, Милош Ковачевић, Мато Пижурица, Вељко Брборић, прир. Милош Ковачевић), који обједињује реферате са округлог стола $A \kappa-$ туелна питања српског правописа, покренута су поједина питања статуса писама у важећем правопису. Сва три зборника чине природну целину и са зборником радова Српски језик и ћирилица данас Андрићевог института из 2017. године (главни и одговорни уредник Емир Кустурица, уредници Милош Ковачевић и Александра Вранеш). Наведени зборници радова сведоче да се у решавање статуса српске ћирилице нису укључили само србисти као заинтересовани појединци већ и кључне националне културне и научне институције: Академија наука и умјетности Републике Српске, Матица српска у Србији, затим њено Друштво чланова у Црној Гори и Друштво чланова Матице српске у Републици Српској, Андрићев институт и др. И Српска академија наука и уметности, судећи по изјави њеног председника Владимира Костића, такође је решила „да најмање два пута годишње [...] проговори о неким од кључних проблема нашег друштва, да покушамо да се позабавимо свим стварима које нас потресају, од демографије и родних разлика и могућности при запошљавању, преко геостратешких проблема, до тема образовања, културе, писма“" (у тексту САHУ покреће разговоре о виталним темама за Србију, „Политика“, 16. јануар 2020, 12).

5. Коначно, 2021. године у издању Међународног славистичког центра појавио се и зборник Употреба ћирилице у јавном простору: Службена и јавна употреба ћирилице. Поред излагања са описаног округлог стола из септембра 2019, у зборнику су се нашла и до овог тренутка необјављена документа: предлози двају закона Министарства културе и информисања из 2004. године (Закон о службеној употреби језика и писама и Закон о националном службеном језику и юеговом матичном писму) и последњи предлози измена и допуна Закона. Од марта 2021. и београдске „Вечерње новости“ покренуле су уз велику организациону подршку уредника Бранислава Ђорђевића акцију Зашто држава не итити ћирилииу, у оквиру које су у додатку „Култура“, који излази уторком, значајни научници из различитих области (Вања Станишић, Александар Јовановић, Зоран Аврамовић и др) и књижевници (Драган Хамовић, Матија Бећковић, Миро Вуксановић, Горан Петровић, Анђелко Анђушић, Ранко Рисојевић, Душко Бабић, Лабуд Драгић и др) серијом текстова покушавали да дају одговор на питање постављено при именовању акције. Штета је што сви 
ови текстови још увек нису обједињени у једном колективном издању, које би било још један јединствен документ о борби за очување нашег писма.

6. Акција „Вечерњих новости“ преименована је, али не и завршена, у тренутку када је, по убрзаној процедури, на Дан српског јединства усвојен Закон о употреби српског језика у јавном животу и заштити и очувағу ћириличог писма, истовремено у Републици Србији и Републици Српској. Предлагачи измена и допуна Закона о службеној употреби језика и писама, из којих су, готово неизмењене, преузете и многе одредбе за овај новоусвојени Закон, тим поводом су се огласили у „Вечерњим новостима“ текстом Коначно Закон о српском језику и ћирилиции (21. септембар 2021, стр. 19). У њему је закључено: „Зато овај Закон треба схватити и прихватити као први корак у заштити српског језика и ћирилице. Као својеврсну подсетницу Србима да би било срамота да законом буду присиљавани како би се очитовали као Срби. Закон тако представља крај убеђивања с политичарима да морају да увиде колико је значајна одбрана српске културне ћириличке баштине с једне стране, а с друге стране представља почетак борбе у којој ће усвајање и примена овог закона иницирати промену потпуно анахроног и суштински антисрпског и антиуставног Закона о службеном језику и писмима, из 1991. године.“

Борба за очување српске ћирилице, дакле, није завршена доношењем новог закона, који магловито коегзистира са анахроним законом из 1991. године. Борба је сада суштински пренета на медијски и образовни терен. На првом терену, и новим законом је српска ћирилица као обавезна сведена само на државне медије (РТС и РТВ), као и на државну телевизију у Републици Српској, али не и на медије са националном фреквенцијом, иако (зло)употребљавају националне ресурсе. ${ }^{1}$ Дакле, суштински се заправо ништа није променило. Опстала је српска ћирилица међу бројним дневним новинама које излазе на латиници („Blic“", „Kurir“, „Informer“, „,Srpski telegraf“, „Objektiv“, „24 sata“, „Alo“, „Danas“ итд), наравно, само

1 У Члану 3, именованом као „Обавезна употреба српског језика и ћириличког писма“, између осталог пише: „Српски језик и ћириличко писмо, као матично писмо, обавезно се употребљава и у раду и пословању, односно обављању делатности:

1) привредних друштава и других облика организовања који послују односно обављају делатност са већинским учешћем јавног капитала;

2) привредних друштава и других облика организовања у области научноистраживачке делатности који се не оснивају по прописима о јавним службама а који послују односно обављају делатност са већинским учешћем јавног капитала;

3) професионалних и струковних удружења која представљају своју област на националном и међународном нивоу;

4) Јавне медијске установе 'Радио-телевизија Србије' и Јавне медијске установе 'Радио-телевизија Војводине', у складу са законом којим се уређују јавни медијски сервиси и овим законом.“ 
у „Политици“ и „Вечерњим новостима“. И правилност у журналистичким поставкама према српској ћирилици остала је неизмењена: док су медији који користе ћирилицу („Политика“, „Вечерње новости“, „Радио-телевизија Србије“, „Печат“ и др) у први план истицали потребу да се ћирилица заштити и очува, медији штампани латиницом („Danas“, „N1“, „Nedeljnik“ и др), углавном са страним већинским власништвом, подвлачили су како се заправно суптилно покушава дискриминисати латиница.

На другом, образовном терену, статус српске ћирилице био би побољшан и уколико би предмет Српски језик и књижевност добио натпредметни статус у нашим основним и средњим школама, на чему србисти убрзано раде углавном преко активности у оквиру Интеркатедарских конференција које се сваке године одржавају у јуну у Научно-образовно-културном центру „Вук Караџић“ у Тршићу. Кроз повећање броја часова Српског језика и књижевности створио би се и простор да ученици дубље увиде културолошки значај ћирилице и више је заволе, што је предуслов за очување нашега националног и матичног писма и у будућности.

Александар М. Милановић* Универзитет у Београду - Филолошки факултет Српски језик са јужнословенским језицима

Студентски трг 3 11000 Београд

Кључне речи: српски језик, српска ћирилица, Закон о службеној употреби језика и писма

Aleksandar M. Milanović

\section{SERBIAN CYRILLIC TODAY}

The paper summarises current language situation reflecting discussions on the Serbian Cyrillic alphabet and the law regulating the official use of language and script. The author examines events and discussions from 2017 onwards.

aleksandar.jus@gmail.com 